36 Michaelis J, Keller B, Haaf G, Kaatsch P. Incidence of childhood malignancies in the vicinity of West German nuclear power plants. Cancer Causes Control 1991:3:255-63.

37 Committee on Medical Aspects of Radiation in the Environment. Second report: investigation of the possible increased incidence of leukaemia in young people near the Dounreay nuclear establishment, Caithness, Scotland. London HMSO, 1988.

38 Fabia J, Thuy TD. Occupation of father at time of birth of children dying of malignant diseases. Br f Prev Soc Med 1974;28:98-100.
39 Lowengert RA, Peters JM, Cicioni C, Buckley J, Bernstein L, Preston-Martin $S$, et al. Childhood leukaemia and occupational and home exposures. 7 Natl Cancer Inst 1987;79:39-46.

40 Buckley JD, Robison LL, Swotinsky R, Garabrant DH, LeBeau M, Manchester $\mathrm{P}$, et al. Occupational exposures of parents of children with acute nonlymphocytic leukaemia: a report from the Childen's Cancer Stud Group. Cancer Res 1989;49:4030-7.

\title{
Geographical distribution of preconceptional radiation doses to fathers employed at the Sellafield nuclear installation, West Cumbria
}

\author{
Louise Parker, Alan W Craft, Julian Smith, Heather Dickinson, Richard Wakeford, Keith Binks, \\ Damien McElvenny, Les Scott, Andy Slovak
}

\begin{abstract}
Objective-To examine whether the geographical distribution of births associated with preconceptional exposure of fathers to radiation at the Sellafield nuclear installation is consistent with the suggestion that this exposure explains the excess of childhood lymphoid malignancy in the adjacent village of Seascale.

Design-Retrospective birth cohort study.

Setting-Cumbria, West Cumbria health district, and Seascale civil parish.

Subjects-The 10363 children born in Cumbria
\end{abstract} during 1950-89 to fathers employed at Sellafield.

Main outcome measures-The doses of external whole body ionising radiation received by fathers at Sellafield in the total time and in the six months before conception of their children; the proportions of the collective doses associated with Seascale and the rest of West Cumbria.

Results -9256 children were born to fathers who had been exposed to radiation before the child's conception. Of these, 7318 had fathers who were exposed in the six months before conception. Overall 7\% (38 person-Sv) of the collective total preconceptional dose and $7 \%$ (3 person-Sv) of the collective dose for the six months before conception were associated with children born in Seascale. Of all the children whose fathers worked at Sellafield, $842(8 \%)$ were born in Seascale. The mean individual doses before conception were consistently lower in Seascale than in the rest of West Cumbria.

Conclusions-The distribution of the paternal preconceptional radiation dose is statistically incompatible with this exposure providing a causal explanation for the cluster of childhood leukaemias in Seascale.

\section{Introduction}

The excess incidence of childhood leukaemia in the coastal village of Seascale, West Cumbria, has received much attention. Gardner et al conducted a case-control study of leukaemia and lymphoma among young people in West Cumbria. ${ }^{12}$ They concluded that there is a statistically significant excess of leukaemia among children whose fathers received fairly high doses of external whole body ionising radiation while employed at the Sellafield nuclear installation before the conception of their children. They suggested that the statistical association between these doses and childhood leukaemia was sufficient in itself to account for the excess leukaemia in children born and diagnosed in Seascale. If this were so paternal preconceptional radiation doses would be concentrated in fathers of children born in Seascale as there is no general excess of childhood leukaemia in the rest of West Cumbria.

We examined whether the geographical distribution of this putative risk factor (paternal preconceptional radiation exposure) in Cumbria is compatible with that of cases of leukaemia among children associated with such exposure.

\section{Subjects and methods}

We compiled a database of Cumbrian children born between 1950 and 1989 to fathers who worked at Sellafield. The year 1950 was taken as the start of the period of interest as it was then that nuclear operations started at Sellafield. ${ }^{3}$

All births registered in the geographical region currently defined by the county of Cumbria (fig 1) (except for a small area for the period 1974-89, which was in Cumberland up to 1974 but is now in North Yorkshire and has about 10 births a year) during the period 1950-89 were identified by means of the register of live births, which was supplied on microfilm by the Office of Population Censuses and Surveys.

All information pertaining to the registered child and his or her parents recorded by the birth certificates was entered on a database by using a Macintosh computer system and the database package 4th Dimension. ${ }^{4}$ The residential address at birth of the mother of each child, as reported on the birth certificate, was assigned a postcode manually from postcode

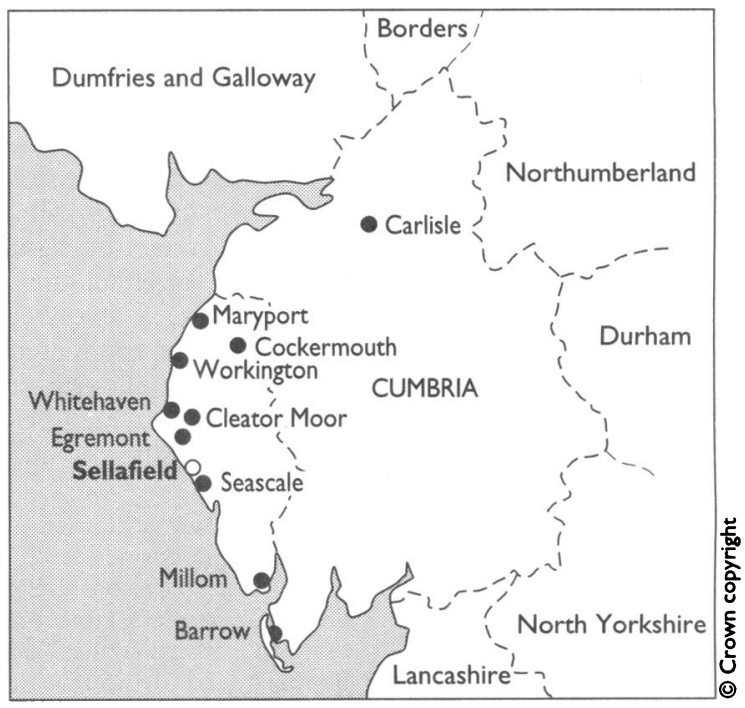

FIG 1-County of Cumbria, England, showing Sellafield nuclear installation and main settlements containing residences of children born installation and main settlements containing residences of children born Cumbria Health Authority and of Seascale civil parish are also shown 
directories and then allocated an eight figure $(100 \mathrm{~m})$ grid reference by means of the Postzon database. ${ }^{5}$

Permission was sought from the management and employee representatives of British Nuclear Fuels and the United Kingdom Atomic Energy Authority to use records held by the employers to facilitate the process of matching Sellafield employees to their Cumbrian born offspring as recorded on the birth register. Advertisements in industry and trade union newspapers informed the employees of the study and gave them the opportunity to opt out. Only four men exercised this right and withdrew from the study. Ethical approval was given by the ethics committee of West Cumbrian Health Authority.

Each person employed at Sellafield by British Nuclear Fuels or the United Kingdom Atomic Energy Authority (or its predecessor, the Ministry of Supply) since 1950 has been given a unique works number and this, as well as the name, sex, dates of employment, and in some instances a residential address, is included in a computer database (the personnel datafile) held by British Nuclear Fuels at Sellafield for epidemiological purposes. The personnel datafile is considered to be almost complete and is regularly updated, although the quality of information has improved with time. In total, 20129 men were employed by British Nuclear Fuels or the United Kingdom Atomic Energy Authority, or both, at Sellafield between 1950 and 1989 and are included in the personnel datafile. The 1988 version of this file was used by Gardner $e t$ al to link case and control fathers to employment at Sellafield. ${ }^{12}$

The Cumbrian born children of Sellafield employees were identified by linking the details of parents from the birth register with the details of employees held in the personnel datafile and employee dossiers. This matching exercise was conducted in two stages. Firstly we conducted a computer matching exercise based on a Soundex ${ }^{6}$ match of surnames on the personnel datafile and birth register to produce a list of possible offspring for each male employee. Secondly, a clerical team working at Sellafield examined the list of possible children for each employee and verified these potential matches by comparing information on the birth certificate with that in the personnel dossiers.

For those men who had left Sellafield to take up employment at another establishment within the industry, information was sought from employee dossiers held at those sites (since employee dossiers may have moved between sites with the employee).

Summaries of the dose of external whole body ionising radiation for each year were obtained from the computer database of British Nuclear Fuels for all employees who were identified as fathers of Cumbrian born children. The summaries include all available doses of radiation recorded while fathers were employed at nuclear installations other than Sellafield. These annual dose summaries are the only dose data which it is currently practicable to use for such a large number of people, and the database has been audited, on a sample basis, by the National Radiological Protection Board..$^{7}$ The 1988 version of this was used in the West Cumbrian case-control study.'

Radiation doses received by fathers before the conception of their children were calculated as $(a)$ the total dose preconceptional-that is, all doses received up to 266 days ( 38 weeks) before the date of birth of the child (assuming an average gestation of 280 days from the last menstrual period and 266 days from fertilisation) and $(b)$ the dose received in the six months before conception. These were the two periods used by Gardner et al. ${ }^{1}$ Doses for part years were determined by directly proportioning the relevant annual doses, as was done by Gardner et al. ${ }^{9}$ Radiation doses were also categorised by magnitude following the method used by Gardner et al: $0,1-49,50-99$, and $\geqslant 100 \mathrm{mSv}$ for total preconceptional doses and $0,0 \cdot 1-4 \cdot 9$, $5.0-9 \cdot 9$, and $\geqslant 10 \mathrm{mSv}$ for doses over the six months immediately before conception. ${ }^{1}$ Thus the final database included all men employed at Sellafield linked to their Cumbrian born children with their associated six month and total preconceptional radiation doses.

The geographical distribution of these doses was generated by using the geographical information system ARC/INFO. ${ }^{111}$ Each birth to a Sellafield employee was allocated to Seascale civil parish, West Cumbria outside Seascale, or the remainder of Cumbria, depending on the grid reference of the maternal residence at the birth of the child. Digitised boundaries of civil parishes and other areal units within Cumbria were obtained from Ordnance Survey. ${ }^{1213}$ All addresses within Seascale civil parish and the immediate vicinity were checked to verify correct allocation.

The collective paternal preconceptional doses (expressed in person-Sv) for any particular areal unit were calculated by summing the individual doses for all those matched children located (by maternal residential address at birth) within the areal unit. Mean individual doses were calculated by dividing the collective dose by the number of children with an associated dose born within the areal unit under consideration. Preconceptional doses associated with children of the same father were treated separately.

\section{VALIDATION STUDY}

We performed a validation of the matching process in which postal questionnaires were sent to 1835 men employed at Sellafield selected at random from those for whom a residential address was included in the personnel datafile and for whom death was not recorded. Sixty two questionnaires were returned by the Post Office. Comparison of the replies received from 1244 employees $(70 \%$ of those who received the questionnaire) with the results from the matching process showed disagreement for $17(1.9 \%)$ of the children conceived during or after the father's employment at Sellafield. Seven $(0.8 \%)$ were overmatchedthat is, matched but not reported on the questionnaire -while $10(1 \cdot 1 \%)$ were undermatched. In five of the seven apparently overmatched cases the child was almost certainly the offspring of the matched father but had not been reported because the father had interpreted the word "children" on the questionnaire to exclude adult offspring, those who had died, or those of a previous marriage. Of the 10 apparently missed children, one had a cancelled birth registration (and so may have been adopted); three reported children could not be found on our births database, on the original births register, or on the birth indexes at the Office of Population Censuses and Surveys; and one child was missed because the father's name was not on the birth registration. Hence, although there was disagreement in $17(1.9 \%)$ cases, the actual error was estimated to be seven $(0 \cdot 8 \%)$ cases. Two $(0 \cdot 2 \%)$ were overmatched and five $(0.6 \%)$ were undermatched.

\section{Results}

The Cumbrian birth register contains details of 267426 live births registered within Cumbria over the 40 year period $1950-89$. A total of $10363(3.9 \%)$ of these children were linked to 5776 men who were employed at Sellafield by British Nuclear Fuels or the United Kingdom Atomic Energy Authority at or before the child's conception. A further 297 "queried" employee-child matches were associated with 112 employees (table I); 154 of these could have been associated with a paternal preconceptional radiation dose. These ambiguous matches will remain unresolved as sources of information have been exhausted. None 


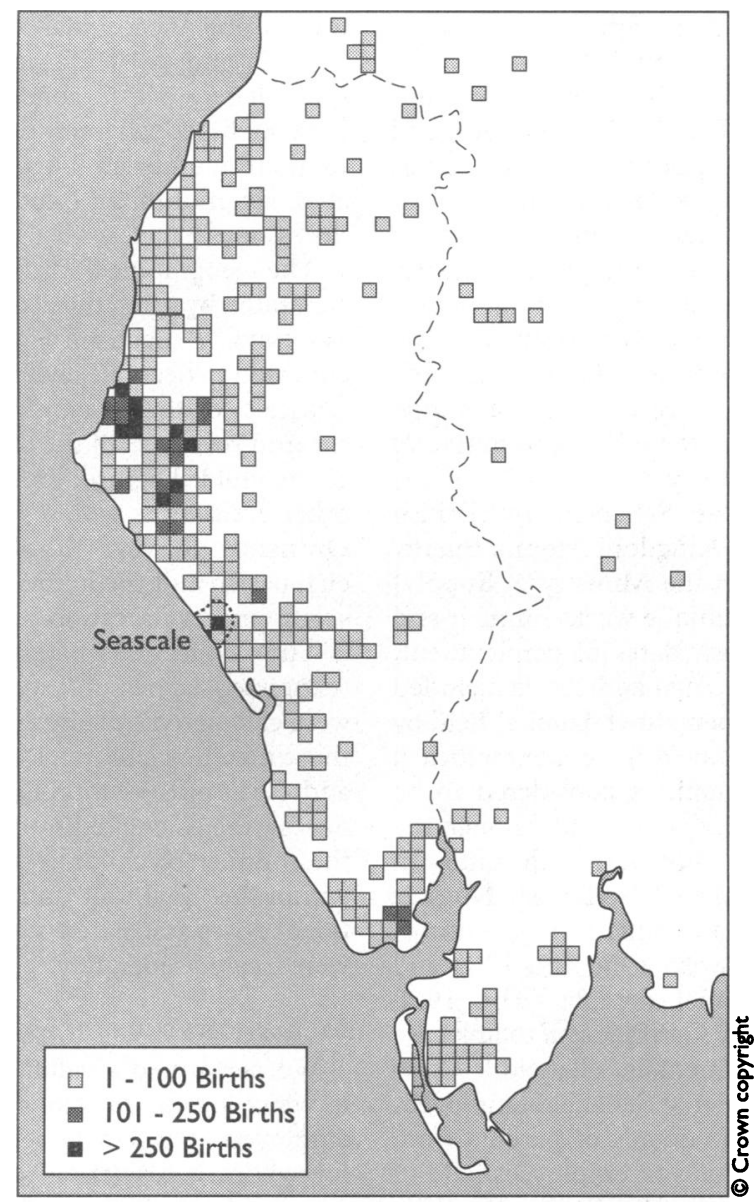

FIG 2-Areal distribution in West Cumbria and immediately surrounding area of maternal residences at birth of children born during 1950-89 to fathers employed at Sellafield by British Nuclear Fuels or United Kingdom Atomic Energy Authority who were conceived after start of this employment. Areal density based on number of births in $1 \mathrm{~km}$ square of National Grid

of the 297 queried children, however, is recorded as having a maternal address in Seascale at birth.

In addition 13 employees were excluded from the matching procedure; 11 as no information other than their surname and date of birth was held by British Nuclear Fuels and two whose dossiers were untraced. None of these 13 had a record of radiation dose. Of the children of the Sellafield workforce, 9971 (96\%) were born in West Cumbria, most in the settlements to the north of Sellafield (fig 2). Of the 10363 children, $9256(89 \%)$ were born to fathers with a preconceptional radiation dose and $7318(71 \%)$ to fathers with a radiation dose in the six months before conception.

Tables II and III describe the geographical and temporal distributions of these births to the Sellafield workforce and the associated preconceptional radiation doses. The collective total dose associated with these children was 539 person-Sv, a mean individual dose of $58 \mathrm{mSv}$ per paternally exposed child (that is, a child conceived after paternal exposure to radiation). The collective dose in the six months before conception was 44 person-Sv, a mean dose of $6 \mathrm{mSv}$ per child. For the

TABLE I-Summary of unresolved employee-child matches for those children conceived after start of possible paternal employment at Sellafield

\begin{tabular}{lcccc}
\hline $\begin{array}{l}\text { Length of employment } \\
\text { of father }\end{array}$ & No of employees & No of children & $\begin{array}{c}\text { No of children with possible } \\
\text { link with possible } \\
\text { preconceptional dose }\end{array}$ & $\begin{array}{c}\text { No born in } \\
\text { Seascale }\end{array}$ \\
\hline 1-3 Months & 18 & 47 & 23 & 0 \\
3-12 Months & 46 & 131 & 54 & 0 \\
1-3 Years & 24 & 46 & 45 & 0 \\
>3 Years & 19 & 46 & 27 & 0 \\
Unknown & 5 & 27 & 154 & 0 \\
\hline Total & 112 & 297 & & \\
\hline
\end{tabular}

842 children born in Seascale $(774(92 \%)$ of whom had an associated paternal preconceptional dose) the corresponding doses were 38 person-Sv ( $7 \%$ of the collective total dose), a mean dose of $49 \mathrm{mSv}$ per paternally exposed child and 3 person-Sv (7\% of the collective six month dose), a mean dose of $4 \mathrm{mSv}$ per paternally exposed child. For children falling within the highest categories of total and six month dose, $7 \%$ (20 person-Sv) and 6\% (1 person-Sv) of the respective collective doses were associated with Seascale, and mean doses per paternally exposed child for children born in Seascale were lower than those for children born in West Cumbria outside Seascale.

Figure 3 shows the collective paternal total preconceptional dose by areal density for 1950-89. The equivalent density for the six month dose is similar. The areal densities of the total and six month collective doses follow closely the density of births (fig 2 ).

\section{Discussion}

COMPARISON WITH WEST CUMBRIA CASE-CONTROL STUDY

A possibly causal association between paternal preconceptional radiation exposure and childhood leukaemia (and non-Hodgkin's lymphoma) has been identified by Gardner $e t$ al after their case-control study of leukaemia and lymphoma in West Cumbria. ${ }^{1}$ They suggested that the excess of haematological malignancies in children resident in Seascale could be effectively explained by the radiation doses received by their fathers before the conception of the affected child during the course of their employment at Sellafield. If

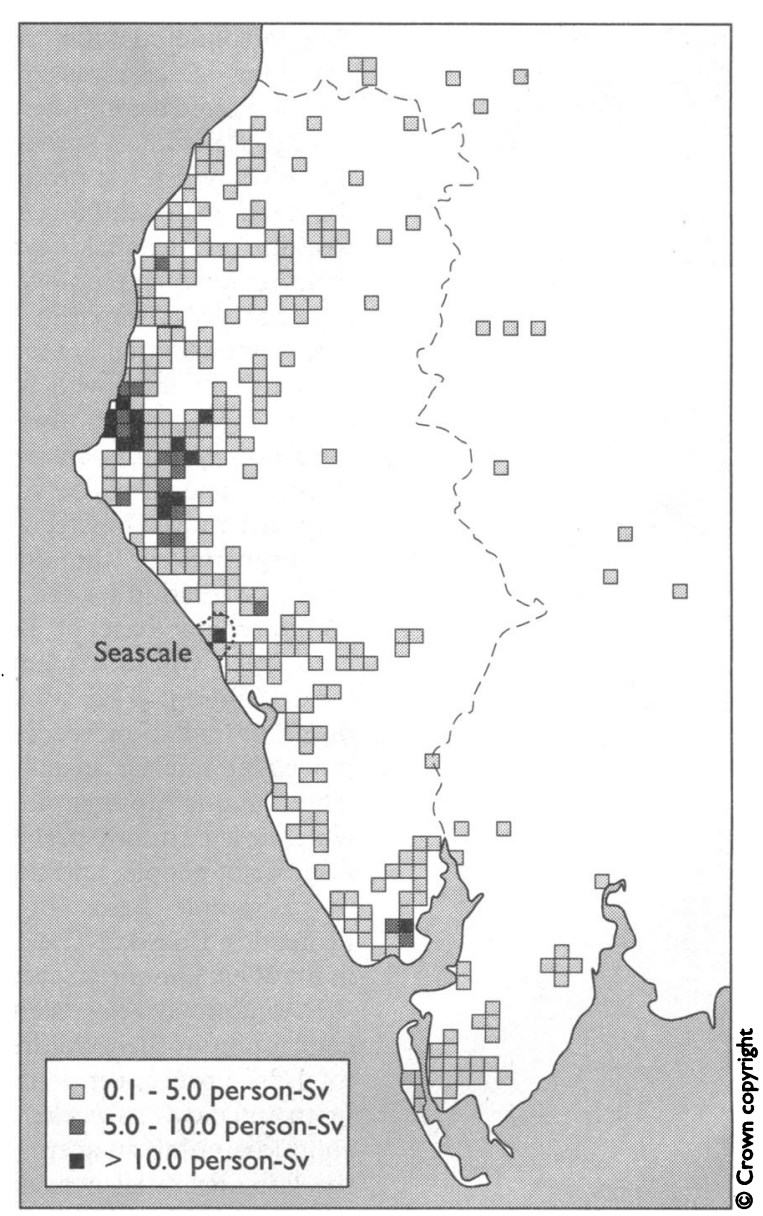

FIG 3-Areal distribution in West Cumbria and immediately surrounding area (by maternal residence at birth) of collective paternal total preconceptional radiation dose associated with children borm during 1950-89 to fathers employed at Sellafield by British Nuclear Fuels or United Kingdom Atomic Energy Authority at or before date of conception. Areal density is based on sum of individual total doses of radiation received by fathers before conception associated with births in $1 \mathrm{~km}$ square of National Grid 
TABLE II-Distribution of number of births, collective dose (person-Sv), and mean individual dose (mSv) between Seascale civil parish, West Cumbria health district outside Seascale, and Cumbria outside West Cumbria for children borm in Cumbria (1950-89) to fathers employed at Sellafield before conception of child and various categories of total paternal preconceptional radiation dose

\begin{tabular}{|c|c|c|c|c|c|c|c|c|c|c|c|c|c|c|c|}
\hline \multirow[b]{2}{*}{ Data by year } & \multicolumn{4}{|c|}{ Dose category for Seascale (mSv) } & \multicolumn{5}{|c|}{ Dose category for West Cumbria outside Seascale (mSv) } & \multicolumn{6}{|c|}{ Dose category for Cumbria outside West Cumbria (mSv) } \\
\hline & 0 & $1-49$ & $50-99$ & $\geqslant 100$ & $>0$ & 0 & $1-49$ & $50-99$ & $\geqslant 100$ & $>0$ & 0 & $1-49$ & $50-99$ & $\geqslant 100$ & $>0$ \\
\hline \multicolumn{16}{|l|}{ 1950-9: } \\
\hline No of births & 43 & 183 & 20 & 9 & 212 & 403 & 1047 & 237 & 172 & 1456 & 28 & 20 & 2 & 0 & 22 \\
\hline Collective dose (person-Sv) & 0.0 & $3 \cdot 1$ & 1.4 & $1 \cdot 3$ & $5 \cdot 8$ & 0.0 & 16.9 & $16 \cdot 9$ & $30 \cdot 3$ & $64 \cdot 2$ & 0.0 & 0.3 & 0.1 & 0.0 & 0.4 \\
\hline Mean dose $(\mathrm{mSv})$ & 0.0 & $17 \cdot 0$ & 69.5 & 141.8 & $27 \cdot 3$ & 0.0 & $16 \cdot 2$ & $71 \cdot 4$ & $176 \cdot 4$ & $44 \cdot 1$ & 0.0 & 13.6 & $65 \cdot 2$ & 0.0 & $18 \cdot 3$ \\
\hline \multicolumn{16}{|l|}{ 1960-9: } \\
\hline No of births & 15 & 159 & 72 & 66 & 297 & 230 & 1417 & 504 & 574 & 2495 & 19 & 91 & 10 & 16 & 117 \\
\hline Collective dose (person-Sv) & 0 & $3 \cdot 2$ & $5 \cdot 3$ & $11 \cdot 6$ & $20 \cdot 1$ & 0 & $27 \cdot 9$ & $36 \cdot 2$ & $109 \cdot 1$ & $173 \cdot 1$ & 0 & 1.4 & 0.8 & $2 \cdot 7$ & 4.9 \\
\hline Mean dose (mSv) & 0 & $20 \cdot 3$ & $73 \cdot 1$ & $176 \cdot 0$ & $67 \cdot 7$ & 0 & $19 \cdot 7$ & $71 \cdot 8$ & 190.0 & $69 \cdot 4$ & 0 & 15.5 & $78 \cdot 3$ & $168 \cdot 1$ & $41 \cdot 7$ \\
\hline \multicolumn{16}{|l|}{ 1970-9: } \\
\hline No of births & 8 & 102 & 19 & 22 & 143 & 130 & 923 & 251 & 332 & 1506 & 24 & 64 & 14 & 4 & 82 \\
\hline Collective dose (person-Sv) & 0.0 & 1.6 & $1 \cdot 3$ & $4 \cdot 1$ & $7 \cdot 0$ & 0.0 & $16 \cdot 1$ & $17 \cdot 8$ & $63 \cdot 4$ & $97 \cdot 3$ & 0.0 & $1 \cdot 2$ & 1.0 & 0.9 & $3 \cdot 2$ \\
\hline Mean dose (mSv) & 0.0 & 15.5 & 69.9 & 184.5 & $48 \cdot 8$ & 0.0 & 17.5 & $70 \cdot 8$ & 190.9 & $64 \cdot 6$ & 0.0 & $19 \cdot 3$ & $70 \cdot 2$ & $233 \cdot 3$ & $38 \cdot 4$ \\
\hline \multicolumn{16}{|l|}{ 1980-9: } \\
\hline No of births & 2 & 92 & 15 & 15 & 122 & 192 & 1696 & 511 & 510 & 2717 & 13 & 70 & 11 & 6 & 87 \\
\hline Collective dose (person-Sv) & 0.0 & $1 \cdot 2$ & 1.0 & $3 \cdot 0$ & $5 \cdot 1$ & 0.0 & $29 \cdot 5$ & $36 \cdot 0$ & $90 \cdot 2$ & 155.8 & 0.0 & 0.9 & 0.8 & 0.8 & $2 \cdot 5$ \\
\hline Mean dose (mSv) & 0.0 & $13 \cdot 3$ & $64 \cdot 5$ & $197 \cdot 4$ & $42 \cdot 2$ & 0.0 & $17 \cdot 4$ & $70 \cdot 5$ & $177 \cdot 0$ & $57 \cdot 3$ & 0.0 & 12.9 & $73 \cdot 1$ & $138 \cdot 6$ & $29 \cdot 2$ \\
\hline \multicolumn{16}{|l|}{ 1950-1989: } \\
\hline No of births & 68 & 536 & 126 & 112 & 774 & 955 & 5083 & 1503 & 1588 & 8174 & 84 & 245 & 37 & 26 & 308 \\
\hline Collective dose (person-Sv) & 0.0 & $9 \cdot 2$ & 8.9 & $19 \cdot 9$ & $38 \cdot 0$ & 0.0 & $90 \cdot 4$ & $106 \cdot 9$ & 293.0 & $490 \cdot 4$ & 0.0 & 3.8 & $2 \cdot 7$ & $4 \cdot 5$ & 11.0 \\
\hline Mean dose (mSv) & 0.0 & $17 \cdot 1$ & $71 \cdot 0$ & $177 \cdot 8$ & $49 \cdot 1$ & 0.0 & $17 \cdot 8$ & $71 \cdot 1$ & $184 \cdot 5$ & $60 \cdot 0$ & 0.0 & $15 \cdot 6$ & 73.0 & $171 \cdot 4$ & $35 \cdot 6$ \\
\hline
\end{tabular}

TABLE III-Distribution of number of births, collective dose (person-Sv), and mean individual dose (mSv) between Seascale civil parish, West Cumbria health district outside Seascale, and Cumbria outside West Cumbria for children born in Cumbria (1950-89) to fathers employed at Sellafield before conception of child and various categories of paternal radiation dose six months before conception of child

\begin{tabular}{|c|c|c|c|c|c|c|c|c|c|c|c|c|c|c|c|}
\hline \multirow[b]{2}{*}{ Data by year } & \multicolumn{4}{|c|}{ Dose category for Seascale (mSv) } & \multicolumn{5}{|c|}{ Dose category for West Cumbria outside Seascale (mSv) } & \multicolumn{6}{|c|}{ Dose category for Cumbria outside West Cumbria (mSv) } \\
\hline & 0 & $0 \cdot 1-4 \cdot 9$ & $5 \cdot 0-9 \cdot 9$ & $\geqslant 10$ & $>0$ & 0 & $0 \cdot 1-4 \cdot 9$ & $5 \cdot 0-9 \cdot 9$ & $\geqslant 10$ & $>0$ & 0 & $0 \cdot 1-4 \cdot 9$ & $5 \cdot 0-9 \cdot 9$ & $>10$ & $>0$ \\
\hline \multicolumn{16}{|l|}{ 1950-9: } \\
\hline No of births & 47 & 137 & 41 & 30 & 208 & 611 & 600 & 319 & 329 & 1248 & 42 & 4 & 1 & 3 & 8 \\
\hline Collective dose (person-Sv) & 0.0 & 0.3 & 0.3 & 0.5 & $1 \cdot 1$ & 0.0 & $1 \cdot 3$ & $2 \cdot 3$ & $6 \cdot 1$ & $9 \cdot 7$ & 0.0 & $<0 \cdot 1$ & $<0 \cdot 1$ & $<0.1$ & $0 \cdot 1$ \\
\hline Mean dose (mSv) & $0 \cdot 0$ & $2 \cdot 3$ & $6 \cdot 7$ & $16 \cdot 2$ & $5 \cdot 2$ & 0.0 & $2 \cdot 2$ & $7 \cdot 1$ & $18 \cdot 5$ & $7 \cdot 8$ & 0.0 & $2 \cdot 1$ & $6 \cdot 2$ & $15 \cdot 7$ & $7 \cdot 7$ \\
\hline \multicolumn{16}{|l|}{ 1960-9: } \\
\hline No of births & 24 & 221 & 41 & 26 & 288 & 891 & 955 & 437 & 442 & 1834 & 99 & 27 & 4 & 6 & 37 \\
\hline Collective dose (person-Sv) & 0.0 & 0.4 & $0 \cdot 3$ & $0 \cdot 4$ & $1 \cdot 1$ & 0.0 & $2 \cdot 1$ & $3 \cdot 2$ & 6.9 & $12 \cdot 3$ & 0.0 & 0.1 & $<0 \cdot 1$ & $0 \cdot 1$ & 0.2 \\
\hline Mean dose (mSv) & 0.0 & $2 \cdot 0$ & 6.6 & $15 \cdot 7$ & 3.9 & 0.0 & $2 \cdot 3$ & $7 \cdot 4$ & $15 \cdot 7$ & $6 \cdot 7$ & 0.0 & 2.0 & $7 \cdot 1$ & $12 \cdot 2$ & $4 \cdot 2$ \\
\hline \multicolumn{16}{|l|}{ 1970-9: } \\
\hline No of births & 15 & 108 & 16 & 12 & 136 & 506 & 617 & 224 & 289 & 1130 & 98 & 6 & 1 & 1 & 8 \\
\hline Collective dose (person-Sv) & 0.0 & 0.2 & $0 \cdot 1$ & $0 \cdot 2$ & 0.5 & 0.0 & 1.2 & 1.6 & $4 \cdot 8$ & $7 \cdot 6$ & 0.0 & $<0.1$ & $<0.1$ & $<0.1$ & $<0.1$ \\
\hline Mean dose (mSv) & 0.0 & 1.7 & $7 \cdot 4$ & $16 \cdot 6$ & 3.7 & 0.0 & $2 \cdot 0$ & $7 \cdot 3$ & $16 \cdot 6$ & 6.8 & 0.0 & $2 \cdot 1$ & 9.9 & $13 \cdot 7$ & $4 \cdot 5$ \\
\hline \multicolumn{16}{|l|}{ 1980-9: } \\
\hline No of births & 10 & 99 & 5 & 10 & 114 & 626 & 1542 & 413 & 328 & 2283 & 76 & 21 & 2 & 1 & 24 \\
\hline Collective dose (person-Sv) & 0.0 & 0.1 & $<0.1$ & $0 \cdot 2$ & $0 \cdot 3$ & 0.0 & $2 \cdot 6$ & 3.0 & $5 \cdot 3$ & $10 \cdot 9$ & 0.0 & $<0.1$ & $<0 \cdot 1$ & $<0.1$ & 0.1 \\
\hline Mean dose (mSv) & 0.0 & $1 \cdot 3$ & $6 \cdot 3$ & $17 \cdot 0$ & 2.9 & 0.0 & 1.7 & $7 \cdot 2$ & $16 \cdot 2$ & $4 \cdot 8$ & 0.0 & $1 \cdot 4$ & 7.5 & $12 \cdot 6$ & $2 \cdot 4$ \\
\hline \multicolumn{16}{|l|}{ 1950-89: } \\
\hline No of births & 96 & 565 & 103 & 78 & 746 & 2634 & 3714 & 1393 & 1388 & 6495 & 315 & 58 & 8 & 11 & 77 \\
\hline Collective dose (person-Sv) & 0.0 & $1 \cdot 1$ & 0.7 & $1 \cdot 3$ & 3.0 & 0.0 & $7 \cdot 3$ & $10 \cdot 1$ & $23 \cdot 1$ & $40 \cdot 5$ & 0.0 & 0.1 & $<0.1$ & 0.1 & 0.3 \\
\hline Mean dose (mSv) & 0.0 & 1.9 & $6 \cdot 7$ & $16 \cdot 2$ & $4 \cdot 0$ & 0.0 & $2 \cdot 0$ & $7 \cdot 3$ & $16 \cdot 7$ & $6 \cdot 2$ & 0.0 & 1.8 & $7 \cdot 5$ & $13 \cdot 3$ & $4 \cdot 0$ \\
\hline
\end{tabular}

TABLE IV-Geographical distribution of eight children with leukaemia and two with non-Hodgkin's lymphoma (in brackets) included in the West Cumbria case-control study and known to have fathers with preconceptional exposure to radiation received at Sellafield. ${ }^{19}$ Dose categories are those adopted by Gardner et al ${ }^{1}$

\begin{tabular}{|c|c|c|c|c|c|c|}
\hline \multirow[t]{2}{*}{$\begin{array}{l}\text { Maternal residence at date of birth } \\
\text { of affected child }\end{array}$} & \multicolumn{3}{|c|}{$\begin{array}{l}\text { Total dose (mSv) received by father } \\
\text { before conception }\end{array}$} & \multicolumn{3}{|c|}{$\begin{array}{l}\text { Dose (mSv) received by father in six } \\
\text { months before conception }\end{array}$} \\
\hline & $1-49$ & 50-99 & $\geqslant 100$ & $0 \cdot 1-4.9$ & $5 \cdot 0-9 \cdot 9$ & $\geqslant 10$ \\
\hline $\begin{array}{l}\text { Within Seascale } \\
\text { Outside Seascale }\end{array}$ & $\begin{array}{l}0 \\
3(1)\end{array}$ & $\begin{array}{l}1(1) \\
0\end{array}$ & $\begin{array}{l}3 \\
1\end{array}$ & $\begin{array}{l}1(1) \\
2(1)\end{array}$ & $\begin{array}{l}0 \\
1\end{array}$ & $\begin{array}{l}3 \\
1\end{array}$ \\
\hline
\end{tabular}

this inference is correct then the geographical distribution of the paternal preconceptional radiation dose would reflect the distribution of the excess of the disease and be concentrated within Seascale as there is no evidence of a general excess of childhood leukaemia or lymphoma in West Cumbria outside Seascale. ${ }^{314}$

Our results show that $8 \%$ of children born in Cumbria during 1950-89 to a father employed at Sellafield at or before the child's conception were born in Seascale civil parish and that these children born in Seascale were associated with $7 \%$ of the collective paternal total preconceptional dose and also $7 \%$ of the collective dose in the six months before conception. The associated mean individual preconceptional dose, both total and for six months, was consistently lower for children born in Seascale than for those born in the remainder of West Cumbria (tables II and III).

The collective dose is the standard measure of the total exposure to radiation in a group of people and in this study represents the putative collective excess risk of leukaemia associated with children born in a particular area.

The West Cumbria case-control study conducted by Gardner et al identified all children with leukaemia and lymphoma born in West Cumbria and subsequently diagnosed during 1950-85 while under 25 years of age and still resident in the district. ${ }^{12}$ Table IV gives the distribution of those cases known to be associated with a paternal preconceptional exposure radiation by category of dose and between Seascale and West Cumbria outside Seascale. ${ }^{9}$

To examine the suggestion of Gardner et al that paternal exposure before conception is sufficient to account for the excess childhood leukaemia (and nonHodgkin's lymphoma) which has occurred in Seascale, ${ }^{1}$ the proportion of the risk that would need to be located in Seascale must be estimated from the known distribution of cases.

Since there is an excess of about 10 -fold of cases diagnosed while resident in Seascale ${ }^{3}$ to be accounted for, most if not all of the cases of leukaemia (and nonHodgkin's lymphoma) in children who were also born there would have to be attributable to these radiation doses. From table IV 10 cases of leukaemia and nonHodgkin's lymphoma in West Cumbria are known to be associated with paternal preconceptional radiation exposure. If all 10 of these cases are assumed to be caused by such exposure then, as five of the affected children were born in Seascale, $50 \%$ of the excess risk must be associated with being born in Seascale (95\% 
confidence interval $23 \%$ to $77 \%$, exact binomial method $\left.^{1516}\right)$. Several assumptions concerning the number of cases attributable to paternal preconceptional radiation exposure can be made; but all those assumptions that allow the excess cases in Seascale to be accounted for by their associated paternal exposure imply that a relatively high proportion of the putative risk is associated with birth in Seascale. For example, if only the four cases in the highest categories of dose are attributable to their associated doses then the case distribution (table IV) implies that $75 \%$ (95\% confidence interval $33 \%$ to $95 \%$ ) of the excess risk should be located in Seascale.

These proportions are clearly incompatible with the $7 \%$ of the collective total paternal exposure and $7 \%$ of the collective six month paternal exposure that we found to be associated with birth in Seascale compared with the remainder of West Cumbria. This clear incompatibility also exists if analysis is restricted to the highest categories of dose: $6 \%$ of the collective total paternal exposure and $5 \%$ of the collective six month paternal exposure in these dose categories were located in Seascale. Therefore the discrepancy between the case and dose distributions does not depend on the assumption of a linear, no threshold, dose-response relation.

Alternatively we can consider the incompatibility between the collective dose and excess case distribution by estimating the excess absolute risk coefficients obtained by attributing affected children born and diagnosed in Seascale to the collective doses assigned to this village. For example, attributing the four cases of leukaemia associated with paternal exposure to the collective paternal total preconceptional dose for Seascale offspring of 38 person-Sv would give 0.11 excess cases of leukaemia per person-Sv paternal total preconceptional dose ( $95 \%$ confidence interval 0.03 to $0 \cdot 25$, exact Poisson method $\left.{ }^{15}\right)$. Applying this excess absolute risk coefficient to the 490 person-Sv of collective dose in West Cumbria outside Seascale would produce an expected number of excess cases of leukaemia of 52 (95\% confidence interval 15 to 122$)$. This figure is plainly inconsistent with the maximum number of four children with leukaemia born in West Cumbria outside Seascale which might be attributable to paternal preconceptional doses (table IV). Only the attribution of a single case of leukaemia to the collective dose associated with birth in Seascale would remove this statistical incompatibility.

The case distribution presented in table IV is based on affected children born in West Cumbria and subsequently diagnosed during 1950-85 while under 25 years of age and resident in the district. The collective dose distributions generated by the study reported here are based on children born in Cumbria during 1950-89, so the two studies, although overlapping to a considerable degree, are not entirely coincident in the subjects studied.

This, however, should not affect the validity of the comparisons. Firstly, the proportions of the collective doses for West Cumbria associated with births in Seascale have been consistently low (10\% or below) over the four decades from 1950 (tables II and III) so the conclusions of this study are not dependent on the particular time period selected for the definition of the birth cohort. Secondly, there may be children with leukaemia (or non-Hodgkin's lymphoma) who were born in West Cumbria to exposed fathers but diagnosed while living outside the district and therefore not included in the study of Gardner et al. ${ }^{12}$ For such cases to influence materially the comparisons reported in this paper, however, a disproportionately large number would need to have been born in West Cumbria outside Seascale. There is no reason to expect that affected children born in the rest of West Cumbria should be preferentially diagnosed outside the district. Indeed, the higher socioeconomic class of men in Seascale would suggest that children born in Seascale would be the more mobile group. ${ }^{1718}$ The children with leukaemia and non-Hodgkin's lymphoma falling into this category are currently being identified and will be presented in future analyses.

The annual dose summaries used for these analyses in general exclude those doses resulting from the internal deposition of radionuclides and from neutron exposures in the earlier years of operations at Sellafield. These sources of dose are currently being assessed and added to the database and will be available for future analyses. These doses, however, are generally small in comparison with the doses already included in the database.

This study does not include all children of fathers who have received doses of radiation while working at Sellafield before the child's conception; the children born to employees of contracting firms have not been included unless their fathers have also been employed by British Nuclear Fuels or the United Kingdom Atomic Energy Authority. Although dose records are available at Sellafield for such men, the personal details held by British Nuclear Fuels or the United Kingdom Atomic Energy Authority are not, in general, sufficiently comprehensive to allow an unambiguous link to be made with fathers on the Cumbrian birth register. These exclusions will not affect the conclusions of this study, however, as Gardner et al also excluded such doses (and other occupational doses) from their analyses.

\section{COMPARISON WITH OTHER STUDIES}

Before the report of Gardner and his colleagues there was little if any reliable epidemiological evidence for an association between paternal exposure to radiation before conception and childhood leukaemia. ${ }^{19}$ Subsequently, Little ${ }^{20-23}$ has shown that the results of Gardner et al are statistically inconsistent with those pertaining to children born to Japanese survivors of the atomic bombings of Hiroshima and Nagasaki, who show no detectable excess risk of childhood leukaemia or other cancers. ${ }^{24}$

A case-control study of childhood leukaemia in Canada, in which the paternal dose records of children born around six nuclear facilities in Ontario were examined, found no association between childhood leukaemia and paternal preconceptional radiation exposure. ${ }^{25}$ Similarly, Kinlen et al found no significant excess of childhood leukaemia associated with paternal preconceptiional radiation exposure in the Scottish nuclear industry. ${ }^{26}$ This Scottish casecontrol study includes those cases considered in the earlier Caithness case-control study, which showed that the excess of childhood leukaemia around the Dounreay nuclear installation could not be accounted for by paternal employment in the nuclear industry before the child's conception. ${ }^{27}$ Roman et al found an association between leukaemia and non-Hodgkin's lymphoma in young children and fathers being monitored for external radiation exposure in the period before conception while employed at nuclear installations, but they concluded that this association was unlikely to be causal. ${ }^{28}$

The inconsistency between the results of our study and others throughout the world and those of Gardner et al must provoke speculation as to whether their causal interpretation of the statistical association between paternal exposure and the incidence of childhood leukaemia was perhaps an overinterpretation of a chance finding. We have identified the group of all children born in Cumbria to fathers employed by British Nuclear Fuels or the United Kingdom Atomic Energy Authority at Sellafield who received an 


\section{Epidemiological implications}

- A significant association has been reported between paternal exposure to radiation at Sellafield before conception and incidence of childhood leukaemia

- It has been suggested that this association is sufficient to account for the excess of childhood leukaemia in Seascale, West Cumbria

- This study shows that only $7 \%$ of the putative risk due to such exposure is associated with births in Seascale

- This proportion is incompatible with the proposed explanation for the cases in Seascale because too few cases of leukaemia have occurred in West Cumbria among children born outside Seascale to exposed fathers

- It is highly unlikely that the association between paternal exposure to radiation before conception and childhood leukaemia represents a direct causal relation

occupational radiation dose before the child's conception, and we have used the same or very similar pertinent sources of data as those used in the casecontrol study of Gardner et al. ${ }^{2}$ We have shown that the exposure of the father to radiation before conception is insufficient to explain the excess of cases of childhood leukaemia which have occurred in Seascale.

Recently Kinlen has shown that an important excess of leukaemia and non-Hodgkin's lymphoma has occurred in Seascale among children who are not associated with paternal exposure to radiation in the nuclear industry. ${ }^{29}$ These results are independent of our findings and serve to emphasise that such exposures cannot account for the excess number of cases diagnosed in Seascale.

\section{CONCLUSIONS}

The absence of a comparable excess of childhood leukaemia (or non-Hodgkin's lymphoma) in West Cumbria among children born outside Seascale to fathers employed at Sellafield, despite higher individual paternal doses before conception and a much greater number of such births than in Seascale, makes it unlikely that paternal exposure to radiation before conception is a cause of childhood leukaemia. The cluster of cases of childhood leukaemia in Seascale remains an enigma.

We are grateful to the British Nuclear Fuels and United Kingdom Atomic Energy Authority workforce, management, and representatives for their cooperation with this study, and to other employers, particularly the Atomic Weapons Establishment and Amersham International, within the nuclear industry. We thank the United Kingdom Coordinating Committee on Cancer Research, which funded this project, and the NHS central register, the Office of Population Censuses and Surveys, Ordnance Survey, and the Department of Social Security for help with data collection. We are also grateful to the North of England Children's Cancer Research Fund for the ongoing support it gives to the children's cancer unit, Newcastle.

We thank Dr Leo Kinlen, Oxford; Mrs Sheila Roe,
Mrs Margaret Frost, Miss Ellen Devine, and Mrs Cheryl Fialkowski at British Nuclear Fuels, Sellafield; and Miss Dallas V Law at United Kingdom Atomic Energy Authority, Harwell, for their help. We also thank the clerical assistants at Newcastle and Sellafield. We are grateful to Mr Martin Charlton at Newcastle University for his advice on GIS software and to Dr T J Ratcliffe for his technical support.

1 Gardner MJ, Snee MP, Hall AJ, Powell CA, Downes S, Terrell JD. Results of case-control study of leukaemia and lymphoma among young people near Sellafield nuclear plant in West Cumbria. BMF 1990;300:423-9.

2 Gardner MJ, Hall AJ, Snee MP, Downes S, Powell CA, Terrell JD. Methods and basic data of case-control study of leukaemia and lymphoma among young people near Sellafield nuclear plant in West Cumbria. BMF 1990;300:429-34.

3 Independent Advisory Group. Investigation of the possible increased evidence of cancer in West Cumbria. London: HMSO, 1984.

4 4th Dimension. Design reference manual. Paris: ACIUS Inc \& ACI, 1989

5 Royal Mail Postcode Services. Postzon. Portsmouth: National Postcode Centre, 1992.

6 Findlay W, Watt DA. Pascal. An introduction to methodical programming. London: Pitman Publishing, 1987.

7 Kendall GM, Greenslade E, Wilinson P. Radiation dose histories at British Nuclear Fuels plc, Sellafield. Chilton: National Radiological Protection Board, 1986. (NRPB-M136.)

8 Kendall GM, Muirhead CR, MacGibbon BH, O'Hagan JA, Conquest AJ, Goodill AA, et al. First analysis of the national registry for radiation worker. Chilton: National Radiological Protection Board, 1992. (NRPB-R251.)

9 Gardner MJ. Paternal occupations of children with leukaemia. BMf 1992;305: 715

10 Environmental Systems Research Institute. ARC Version 6.01. Redlands, California: ESRI, 1991.

11 Environmental Systems Research Institute. INFO 9.42. Redlands, California: ESRI, 1991.

12 Ordnance Survey. Boundary line digital map data. London: HMSO, 1992.

13 Ordnance Survey. 1:250,000 Digital map data. London: HMSO, 1990.

14 Draper GJ, Stiller CA, Cartwright RA, Craft AW. Cancer in Cumbria and in the vicinity of the Sellafield nuclear installation, 1963-90. BMF 1993;306:8994.

15 Brenner DJ, Quan $\mathrm{H}$. Confidence limits for low induced frequencies of oncogenic transformation in the presence of a background. Int $\mathcal{F}$ Radiat Biol 1990;57:1031-45.

16 Brenner DJ, Quan H. Exact confidence limits for binomial proportionsPearson and Hartley revisited. Statistician 1990;39:391-7.

17 Gardner MJ, Hall AJ, Downes S, Terrell JD. Follow up study of children born elsewhere but attending schools in Seascale, West Cumbria (schools cohort). $B M 7$ 1987;295:819-22.

18 Gardner MJ, Hall AJ, Downes S, Terrell JD. Follow up study of children born to mothers resident in Seascale, West Cumbria (birth cohort). BMF 1987;295:822-7.

19 Rose KSB. Pre-1989 epidemiological surveys of low-level dose pre-conception irradiation. Fournal of Radiological Protection 1990;10:177-84

20 Little MP. A comparison between the risks of childhood leukaemia from parental exposure to radiation in the Sellafield workforce and those displayed among the Japanese bomb survivors. fournal of Radiological Protection 1990;10:185-98.

21 Little MP. A comparison of the apparent risks of childhood leukaemia from parental exposure to radiation in the six months prior to conception in the Sellafield workforce and the Japanese bomb survivors. Foumal of Radiological Protection 1991;11:77-90.

22 Little MP. A comparison of the risks of childhood leukaemia from parental preconception exposure to radiation in the Sellafield and Dounreay workforces and the Japanese bomb survivors. Fournal of Radiological Protection 1991;11:231-40.

23 Little MP. The risks of leukaemia and non-cancer mortality in the offspring of the Japanese bomb survivors and a comparison of leukaemia risks with those in the offspring of the Sellafield workforce. Foumal of Radiological Protection 1992;12:203-18.

24 Yoshimoto Y, Neel JV, Schull WJ, Kato H, Soda M, Eto R, et al. Malignant tumors during the first 2 decades of life in the offspring of atomic bomb survivors. Am f Hum Genet 1990;46:1041-52.

25 McLaughlin JR, King WD, Anderson TW, Clarke EA, Ashmore JP. Paternal radiation exposure and leukaemia in offspring: the Ontario case-control study. $B M F$ 1993;307:959-66.

26 Kinlen LJ, Clarke K, Balkwill A. Paternal preconceptional radiation exposure in the nuclear industry and leukaemia and non-Hodgkin's lymphoma in

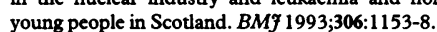

27 Urquhart ID, Black RJ, Muirhead MJ, Sharp L, Maxwell M, Eden OB, et al. Case-control study of leukaemia and non-Hodgkin's lymphoma in children Case-control study of leukaemia and non-Hodgkin's lymphoma in children 818 .

28 Roman E, Watson A, Beral V, Buckle S, Bull D, Baker K, et al. Case-control study of leukaemia and non-Hodgkin's lymphoma among children aged 0-4 years living in west Berkshire and north Hampshire health districts. $B M \boldsymbol{F}$ 1993;306:615-21.

29 Kinlen LJ. Can paternal preconceptional radiation account for the increase of leukaemia and non-Hodgkin's lymphoma in Seascale? BMf 1993;306: 1718-21.

(Accepted 20 August 1993) 